\section{Bojan Kozomara}

CASE REPORT

\section{Treatment of Bilateral Postoperative Aphakia in a Young Patient With Still- Chauffard Syndrome}

\begin{abstract}
An 18-year-old female patient was referred to our clinic with low vision in both eyes. She had been treated for Still-Chauffard syndrome since birth, had choric uveitis and underwent cataract surgery in young childhood; she was since left aphakic in both eyes. After bilateral implantation of Verisyse Aphakia phakic intraocular lense was done, her vision and quality of life improved dramatically over the course of one year.
\end{abstract}

\section{KEY WORDS}

Still-Chauffard syndrome, aphakia, Verisyse aphakia.

DOI: $10.7251 / S M D 1202111 K$

(Scr Med 2012;43:111-2)

\author{
Eye Clinic „Svjetlost“ \\ 7800 o Banja Luka, Republic of Srp- \\ ska, Bosnia and Herzegovina \\ Correspodence \\ Bojan Kozomara, $M D$ \\ Bul. Desanke Maksimović 12 \\ 78000 Banja Luka, Bosnia and \\ Herzegovina \\ Tel/fax: 051/439-592 \\ e-mail:bojan@svjetlost-banjaluka.ba
}

\section{Case presentation}

Still-Chauffard syndrome is a systemic form of juvenile idiopathic arteritis (JIA). ${ }^{1}$ It is present in $20 \%$ of all cases of JIA and equally represented in male and female patients. JIA is characterized by remittent high fevers, maculopapular rash, generalized lymphadenopathy, hepatosplenomegaly and serositis. ${ }^{2}$ Ocular manifestations include a triad of symptoms: band keratopathy, anterior uveitis and cataract.

An 18-year-old female patient was referred to our clinic due to low vision in both eyes. She underwent bilateral cataract surgery when she was 8 years old and was left aphakic in both eyes. Prior to cataract surgery, she had chronic recurrent anterior uveitis in both eyes and was treated with high dose of corticosteroids, both topically and systemically. Her uncorrected visual acuity (UCVA) was 20/800 and visual acuity corrected with+12.0o spherical diopters was 20/60 for the right eye and 20/80 for the left eye. Slit lamp examination showed band keratopathy in both eyes, mild chronic uveitis without Tyndall light and iridodonesis. The fundus was unremarkable. Oculus Pentacam II corneal topography showed low astigmatic patterns and deep anterior chambers in both eyes.

Considering the exam results together with the patient's age and current general health condition, we decided to implant Verisyse Aphakia (Abbott Medical Optics, Inc., Abbott Park, Illinois, USA) phakic intraocular lenses (pIOL) in both eyes. Prior to the surgery, the patient received sub Tenon anesthesia in both eyes. The standard surgical procedure included a clear corneal incision $(5.0 \mathrm{~mm})$, viscoelastic instillation, lens implantation and fixation to the anterior iris; we used an extended 10/0 nylon suture with intra cameral antibiotic administration. There were no postsurgical complications during the follow up period. One week after surgery, UCVA on the right eye was 20/25 and 20/40 on the left eye. One year after surgery UCVA on the right eye was the same, and the left eye had improved to $20 / 25$.

\section{Discussion}

Still-Chauffard syndrome occurs in $20 \%$ of all cases of JIA. Due to treatment of the specific ocular symptoms, these patients have a long-term exposure to the topical and systemic corticosteroids that can result in subsequent cataract formation.

This case was the first case of pIOL implantation for aphakia correction in a young patient in our clinic and in our region. Nonetheless, studies ${ }^{3}$ with the same type of pIOL show similarly beneficial results, without intra-operative or postoperative complications. Even though our patient was young and had a chronic systemic illness, her lenses remained stabile in the anterior chambers, there was no endothelial cell loss and she did not experience any increase in intraocular pressure. 
In summary, our findings show that implatantion of phaking itraocular lense is a safe procedure not only for elderly aphakic patients, but also for young ones as well.

\section{References}

1. Kanski JJ. Clinical Ophthalmology. London: ButterworthHeinemann, 2003.
2. Stanojević-Paović A, Milenković S, Zlatanović G. Systemic Eye Diseases. Belgrade: Faculty of Medicine, University of Belgrade, 1993. [In Serbian]

3. Chen Y, Liu Q, Xue C, Huang Z. Three year follow-up of secondary anterior iris fixation of an aphakic intraocular lens to correct aphakia. J Cataract Refract Surg 2012;38:1595-601.

\section{Lečenje bilateralne postoperativne afakije mladog pacijenta obolelog od Still-Chauffard sindroma}

\section{Bojan Kozomara}

\section{APSTRAKT}

Osamnaestogodišnja djevojka javila se u našu kliniku radi lošeg vida na oba oka. Od djetinjstva se liječi od Still Chauffard-ovog sindroma, sa hroničnim uveitisom i kataraktama koje su operisane u ranoj mladosti i nakon kojih je bila afakna na oba oka. U našoj klinici urađena je bilateralna implantacija fakičnih intraokularnih sočiva (Verisyse Aphakia), nakon čega su se vidna oštrina i kvalitet života drastično popravili u periodu od jedne godine.

\section{KLJUČNE RIJEČI}

Still-Chauffard syndrome, afakija, Verisyse Aphakia. 